\title{
The motivation of EFL public school teachers: what can self-theories tell us?
}

\author{
Fernanda Costa Ribas \\ Universidade Federal de Uberlândia \\ fercribas@yahoo.com.br
}

\begin{abstract}
In this paper, I report on a qualitative research study in progress, carried out with two English teachers, working in elementary education in a public school in Minas Gerais. I sought to investigate the motivation of these teachers, in light of self-theories (MARKUS; NURIUS, 1986; HIGGINS, 1987). Data collection methods include a questionnaire, an interview, classroom notes and video-stimulated recall sessions. Results show the important role played by positive and negative self-beliefs (whether actual or future) in teachers' motivational flux. I conclude the article by emphasizing the need for encouraging the reflection on self-beliefs and affective factors that could impact on action and the sharing of experience in teacher education and in continuing education programs in order to engender a positive motivational cycle in schools.
\end{abstract}

Key-words: teacher motivation, self-beliefs, English teaching, teacher education

\section{Resumo}

Neste artigo, apresento resultados de uma pesquisa qualitativa em andamento, realizada com dois professores de inglês de ensino fundamental de uma escola pública de Minas Gerais. Procuro investigar a motivação desses professores à luz das teorias do 'eu' (MARKUS; NURIUS, 1986; HIGGINS, 1987). Os métodos de coleta de dados incluem um questionário, uma entrevista, notas de campo e sessões de visionamento. Os resultados mostram o importante papel exercido por autocrenças positivas e negativas (tanto atuais como futuras) no fluxo motivacional do professor. Concluo o artigo enfatizando a necessidade de encorajar a reflexão sobre autocrenças e fatores afetivos que impactam na ação, bem como o compartilhamento de experiências em programas de formação inicial e continuada de professores, de forma a engendrar um ciclo motivacional positivo nas escolas. 
Palavras-chave: motivação do professor, autocrenças, ensino de inglês, formação de professores

\section{Introduction}

No one can deny that states, emotions, whether positive or negative, are at the heart of teaching (HARGREAVES, 1998). They play an important role in teachers' lives and come into play when teachers make decisions, develop their practice and reflect on it. For Zembylas (2005), "teaching is more than a body of knowledge or a concrete list of practices or skills; it is a way of being and feeling, historically, in relation to others" (p. 468). Teaching is charged with feelings of fear, doubt, concern, as well as satisfaction and selfrealization. As Dörnyei (2001a) points out, a language teacher who is satisfied with his profession will conduct a lesson with enthusiasm and dedication and these can reflect positively on students' level of motivation and commitment to language learning. However, it is common sense that it is not always an easy task for teachers to be motivated or to maintain their motivation, especially when we consider the public school scenario in Brazil and its setbacks.

But what causes teacher motivation to increase and decrease? According to Walker and Symons (1997) and Dörnyei (2001b), internal (cognitive) influences and external (contextual) influences may affect teacher motivation. Cognitive variables include teachers' beliefs, self-beliefs, expectations, attitudes, conceptions, among others. External influences are related to aspects from the teaching context, such as the class sizes, school resources and facilities, the school norms and collegial relations (DÖRNYEI; USHIODA, 2011). In this article, I focus on the influences of internal factors on the motivation of two English teachers, working in primary education in a public school in the State of Minas Gerais, Brazil, in light of self-theories, such as the self-discrepancy theory (HIGGINS, 1987) and possible selves theory (MARKUS; NURIUS, 1986; MARKUS; WURF, 1987). In the last few years, L2 motivation has been reconceptualized to include notions of self and identity (LEONDARI; SYNGOLLITOU; KIOSSEOGLOU, 1998; LAMB, 2004; DÖRNYEI, 2005; YASHIMA, 2007; KUBANYIOVA, 2009; DÖRNYEI; USHIODA, 2011). It is 14 Horizontes de Linguística Aplicada, ano 11, n. 2, jul./dez. 2012 
believed that possible selves, that is, "visions of the self in a future state" (DÖRNYEI; USHIODA, 2011, p. 80) can exert motivational impact, since these self-guides can foster action; in other words, they can serve as stimulus for teachers to reach a condition where their actual self-images match their future desired ones.

The key questions that guided this investigation are:

1) What kind of images (actual and possible) do the teachers form about themselves?

2) How do these images impact on their motivation to teach?

To address these questions, I reviewed studies on teacher cognition, teacher motivation, and student motivation (PENNINGTON, 1991; WALKER; SYMONS, 1997; DÖRNYEI, 2001a, 2005; BORG, 2003; PRAVER; OGA-BALDWIN, 2008), as well as articles that pointed out the impact of self-theories on behavior (MARKUS; NURIUS, 1986; HIGGINS, 1987; MARKUS; WURF, 1987; OYSERMAN, 2001). Key concepts from these studies will be covered in the following section.

\section{Literature review}

\subsection{Teacher motivation}

Motivation is an immensely complex and intriguing concept that has been investigated in the EFL and ESL field for more than fifty years. Complex in the sense that: it is abstract and not directly observable; it involves a wide range of different factors (from cognitive to social); it is a multidimensional construct that can be analyzed from multiple perspectives and it can vary from person to person, from one situation to another. Intriguing in the sense that although it is hard to understand it due to its complexity, without it, almost nothing is achieved. Therefore, the impact of motivation on behavior is always a provocative topic in the teaching and learning sphere.

The word motivation comes from the Latin verb movere, which means to move, thus implying action. Therefore, motivation is a desire or impulse that makes individuals take action, exert effort and 
persist in a task (BROWN, 1994; DÖRNYEI, 2001b). Walker and Symons (1997, p. 4) add that motivation includes "the conditions and processes that activate, direct, and sustain behavior"; in other words, not only the inner states should be considered when analyzing motivation, but also the contextual factors (conditions) that affect it.

What about teacher motivation? Until very recently, the issue of teacher motivation has not received much attention in the education and applied linguistics field as the topic of student motivation. As Dörnyei and Ushioda (2011) highlight, most research that is being done focuses on job satisfaction, stress and burnout. In the last few years, the literature on teacher motivation started to grow. They mainly address three issues: career choice, complexities in the teaching process and factors that impact on the development of teachers and students (DÖRNYEI; USHIODA, 2011). In this article, I will concentrate on the third issue by showing how internal influences, especially beliefs about the self, may impact on teacher motivation.

Overall, the concept of teacher motivation is not very different from student motivation. According to Morgan, Kitching and O'Leary (2007), teacher motivation means commitment, enthusiasm, energy, effort, desire to learn, as well as a sense of direction and purpose. Intrinsically motivated teachers may engage in the task of teaching because they find it rewarding. The task of contributing to the development of students' understanding and "seeing students responding with enthusiasm and excitement about new ideas can be a source of great satisfaction" (DECI, KASSER; RYAN, 1997, p. 60).

Since it is connected to action, motivation is considered a dynamic process that changes over time "according to the various internal and external influences" (DÖRNYEI, 2001b, p. 47). For Dörnyei (2001a), the temporal dimension is one of the features of teacher motivation; it comprehends the influences that affect the teacher's career (e.g. chances of personal and professional advancement) and the negative influences that may affect a teacher's enthusiasm every day in every lesson, causing a drop in motivation.

Internal characteristics mean cognitive processes within individuals (WALKER; SYMONS, 1997). According to Dörnyei (2001a), some of these influences can be negative to teacher motivation, such as stress and insufficient self-efficacy. On the other 
hand, external influences include aspects of the environment that can also affect the persistence and performance of teachers, such as the classroom atmosphere, available resources, interpersonal relationships among teachers and students, school policies, among others (DÖRNYEI, 2001a). Adverse conditions may prevent teachers from feeling satisfied or intrinsically motivated with their chosen careers.

In this article, I will focus on the concept of teacher self-beliefs to explain the influence of internal features on teacher motivation.

\subsection{Teacher self-beliefs}

Borg (2003) uses the term teacher cognition to denote teachers' knowledge, beliefs, theories, attitude, conceptions, images, perceptions and metaphors. It refers to what teachers think, believe and know about the process of teaching and learning and their own teaching practice. According to the author, teachers have cognitions about all aspects of their work (e.g. about teaching, teachers, learning, students, subject matter, materials), and these are influenced by schooling, professional education, and classroom practices. They may also have cognitions about their self; in other words, they may have self-beliefs.

Self-beliefs are inter-related to action, since they serve as regulators of human behaviors, helping individuals interpret their actions and experiences. They are part of what Borg (2003) calls teacher cognition and consist of the individuals' perceptions, images or representations about themselves. They provide incentives, standards, plans, rules, and scripts for behavior (MARKUS; NURIUS, 1986; MARKUS; WURF, 1987; OYSERMAN, 2001).

Self-concepts comprise a variety of representations about a person's present, past and future. They include a person's possible selves (what the individual might become in the future, involving desired and feared selves) and actual selves (the attributes the individual sees as corresponding to the here-and-now). Also, these representations can be verbal, semantic, affective or imagetic (MARKUS; WURF, 1987). The self-concept is considered a core conception that defines a person's identity and remains more or less stable over time. On the other hand, possible selves are dynamic - they 
are "elements of the self-concept that represent what individuals could become, would like to become, and are afraid of becoming" (RUVOLO; MARKUS, 1992, p. 95) and give "direction and impetus for action, change, and development" (MARKUS; NURIUS, 1986, p. 960). Therefore, they can serve as stimulus and are connected to motivation.

People can form desired (positive), as well as feared (negative) future self-images, which in turn can have distinct consequences for motivation in educational settings. Positive and negative images can be stimulating or imprisoning, as individuals will put effort to achieve or avoid them. Desired images, such as the ideal, the admired, the successful self can facilitate optimism and help teachers see that their actual selves are mutable. However, when teachers form high standards that are impossible to be reached, these can lead to demotivation, because they feel that they will never be able to reach them. Feared images, such as the incompetent, the uncompromised, the unemployed self can also have positive or negative consequences for teacher motivation. They can induce teachers to transform their current reality or stifle their attempts to change.

Among the possible selves individuals project, Higgins (1987) identifies two important domains that can exert a great impact on individuals' behavior and motivation: the ideal self, that is, the attributes the person would like, ideally, to possess and the "ought to" self, that is, "the attributes that someone (yourself or another) believes you should or ought to possess" (HIGGINS, 1987, p. 320).

Although the ideal and the ought-to selves seem similar since they are both related to the achievement of a desired image, the ideal self focuses on the person's wishes and aspirations in order to obtain pleasure or a positive result; it has a promotion focus, while the oughtto self emphasizes the avoidance of negative outcomes. Thus, it has a prevention focus (DÖRNYEI; USHIODA, 2011). In the later, there is a sense of duty and responsibility involved. Boyatzis and Akrivou (2006, apud DÖRNYEI; USHIODA, 2011) highlight that it is hard to distinguish between the ideal and the ought-to selves. How can we know whether an ideal self represents an individual's genuine aspiration or whether it has been influenced by various reference groups to which the individual belongs? 
Higgins (1987) also postulates a third domain called actual self, which embraces the attributes that the person believes to actually possess. The actual self is how individuals see themselves in the hereand-now. According to Higgins' self-discrepancy theory, motivation is the result of the individual's attempt to reduce the discrepancy between the actual and either the ideal self or the ought-to self. When individuals work hard to make their actual self be just like their ideal self or their ought-to self, they can feel highly motivated. In contrast, when they realize their actual self is far from being like either their ideal or their ought-to self, they can experience dissatisfaction and, consequently, a decrease in their motivation. It is important to point out that future self-guides will have the capacity to motivate action when there is a gap between actual selves and future selves (ought-to and ideal images). According to Dörnyei and Ushioda (2011, p. 83), "if there is no observable gap between current and future selves, no increase effort is felt necessary".

Individuals can create as many possible selves as they wish. Oyserman and James (2009) explain that they are usually linked to a variety of social roles and identities of an individual, such as being a teacher, a student, a parent or a husband/wife. However, the types of selves people project, their aspirations, and values are influenced by the social context and their life experiences (MARKUS; NURIUS, 1986; MARKUS; WURF, 1987; OYSERMAN, 2001; DÖRNYEI, 2005; DAY et. al, 2006). For instance, a teacher's experience as a learner in the Brazilian public school setting where it is quite common to find unmotivated teachers who reached a stage of lack of commitment to teaching may lead this teacher to form a feared selfimage of the uncompromised self. This feared representation may cause this teacher to put effort "in trying not to be like that". Energy, effort and persistence characterize teacher motivation.

\section{Methodology of this study}

The results and discussion presented in this article are part of a qualitative research study in progress that has been conducted in Brazil since 2010. The aim of this study is to investigate some of the 
cognitive-affective factors involved in pre- and in-service English teacher practice, and to analyze to what extent these factors are interrelated. The objective is also to explore similarities and discrepancies between pre-service and in-service teachers to what concerns the factors that can influence their practice, when we take into account their teaching contexts and experience. The study comprises three phases, and involves two pre-service and four in-service teachers from public schools with different levels of experience. Results that will be presented concern to phase 2, carried out with in-service teachers who had not completed three years of teaching in the public school context ${ }^{1}$. 3.2 Context and participants

The second phase of the study was carried out with two English teachers in an elementary public school in Minas Gerais; Magda and Leonard. Magda has a major in Languages and Literatures from a federal public university. When data was collected, she was about to finish a Specialization Course in Applied Linguistics and New Technologies in language teaching and learning. She had been teaching 20 hours a week for about a year in the public school context. She had also been working in a private school for four years and in a language institute for eight years. Data was collected with one of her sixth grade groups. Leonard is also graduated in Languages and Literatures from the same university. He has a major in Advertising and Marketing. When data was collected, he was finishing his master's course in American Literature. He had been teaching English 20 hours a week for about a year to elementary students. He had also been working as a private teacher and translator. Before starting working in the public school context, he taught English in private language institutes for about ten years and worked in a private school. Data was collected with one of his eighth grade groups.

3.3 Instruments to collect data

\footnotetext{
${ }^{1}$ Phase 1 was carried out with two pre-service teachers during their teaching practice, while they were teaching elementary students in extension projects at the university. Phase 3 has not initiated yet. This last phase will involve experienced teachers who have been working in public schools for at least 8 years.
} 
The following instruments were used to draw the teachers' profile and to trace their beliefs about the self: a questionnaire composed of close-ended and open-ended questions, a semi-structured interview, classroom notes and video-stimulated recall sessions with the teachers.

In the questionnaire, twenty-four statements about motivation were presented and teachers had to tick the ones that were true for them. The statements were based on a range of intrinsic and extrinsic aspects (e.g. self-efficacy, students' interest, faculty relations, salary) that can be related to teacher motivation, according to results from the works of Coates and Thoresen, 1976; Sinclair and Barnes, 1983; Pennington, 1991; Bishay, 1996; Dörnyei (2001a). The open-ended section included questions to trace teachers' self-beliefs, such as "How do I describe myself nowadays?", "How do I see myself in five years from now?", "What do I want to avoid being?", adapted from a questionnaire by Oyserman et al (2004) that was designed by the authors to understand next year possible selves of eighth grade students enrolled in three middle schools serving low-income families.

The semi-structured interview was held with each teacher. To focus on the intrinsic aspects of their motivation, teachers were asked about: their feelings concerning the teaching career; their motivation to teach English; how they see their role as teachers; their career aims, aspirations and worries. The interviews were audio-recorded, transcribed according to Marcuschi (2000) and analyzed. Content analysis was held based on Gillham's techniques (2000). For each answer, I used the following procedure: first, I identified and underlined key words, that is, words or sentences that were mentioned by the teachers repeatedly. Based on these key-words, I created themes that were later grouped into categories and subcategories in a grid with examples of the teachers' answers (e.g. extrinsic factors that contribute to teacher motivation, such as a good relationship with students).

Four classes of each teacher with the same group of students were videotaped. Classroom notes were also taken and used to triangulate the data. The recordings were used in video-stimulated recall (VSR) sessions between the researcher and each teacher. This is an introspection procedure in which videotaped passages of behavior are replayed to teachers to stimulate recall and discussion of their 
thinking and feelings (POWELL, 2004). VSR sessions are intended to reveal teachers' thoughts, beliefs, decisions, and feelings about specific classroom episodes, as well as the reasons for acting as they do (POWELL, 2004; REITANO, 2006). Participants were asked to view the recorded lessons alone and select extracts to be the focus and stimulus for reflective dialogues with the researcher. They were instructed to choose extracts that represented the most successful and the least successful moments of their lessons. During the sessions, these extracts were replayed and teachers were encouraged to talk about the reasons for choosing them. Based on the teachers' stories and explanations, questions were made to elicit aspects of their motivation and self-beliefs. The sessions were audio-recorded, transcribed and submitted to content analysis.

\section{Interpretive results and discussion}

Analysis of the qualitative data reaffirmed one of the characteristics of teacher motivation pointed out by Dörnyei (2001a): teacher motivation is fragile and, for this reason, it is highly influenced by negative factors. Both participant teachers show conflicting signs of motivation and demotivation, which indicate the "fragile" and varying feature of the phenomenon.

Challenge, satisfaction, happiness, and self-realization suggest their intrinsic motivation to teach:

Leonard: I think this everyday experience is challenging. We have to test different methodologies to see if they work. It is gratifying, because there are a few students who like English very much and their eyes sparkle when you give them a different task.

However, when asked directly whether he is motivated to teach English in the public school context, his answer is:

I try to motivate myself because of my students. My motivation varies a lot according to the students' responses. 
When Leonard says "I try to", it becomes clear the effort he puts on to stay motivated despite the problems he faces every day. Conversely, Magda shows a more optimistic view of her motivation and of her career. She is eager to work as a teacher and believes in the value of the teaching profession, but like Leonard she also mentions negative contextual problems that affect her motivation:

I feel very motivated. I feel happy and self-realized with my profession. My feelings are very optimistic despite all the problems we face on a daily basis and students' misbehavior.

Internal and external influences were identified as affecting the teachers' motivation. Some affected their motivation positively, while others negatively. For example, students' misbehavior, lack of resources and sufficient conditions to deliver classes, high number of students per class, low salary are some of the factors that can cause the teachers' motivation to fall. However, a pleasant atmosphere in the school, and students' high participation and interest in class were pointed out by both teachers as contributing to their enthusiasm.

In the following section, I will discuss the influence of teachers' self-beliefs on the increase and decrease of their motivation. External factors will be discussed in detail in future publications.

\subsection{The power of self-beliefs on teacher motivation}

Self-beliefs are positive or negative verbal, semantic, affective, or imagetic representations that teachers can form about themselves. For Markus and Nurius (1986), they can be present (actual self) or future (desired and feared selves) and they can lead to action, as they provide stimuli for behavior. Possible selves, represented by future desired and feared representations can be, therefore, related to motivation. The impact of self-images on motivation is also highlighted by Higgins' self-discrepancy theory (1987), which states that motivation is the result of an attempt to reduce the discrepancy between the actual and either the ideal self or the "ought to" self.

Authors, such as Markus and Nurius (1986), Markus and Wurf (1987), and Higgins (1987) stress the power of future self

Horizontes de Linguística Aplicada, ano 11, n. 2, jul./dez. 2012 
representations, whether positive or negative, in motivating individuals, especially when there is dissonance between a person's current and desired self-images. However, in the data collected through interviews and VSR sessions, it is possible to observe that actual selves, that is, how individuals see themselves in the present may also function as motivators, especially if these images are positive, because they can increase teachers' optimism and self-efficacy.

Magda sees herself in the here-and-now as a facilitator, someone who is not perfect, but who is willing to try hard to satisfy her students' needs and improve the quality of her lessons:

My role is to present the English language to students in a simpler way, so that they feel it is possible to learn it. Everything I do in my classes is directed to finding ways to facilitate students' access to English, even when I don't get it right.

These positive images may contribute to the increase of her sense of competence, which, in turn, brings her feelings of satisfaction:

I think I am capable of teaching English. I am eager to teach. I know the language I am teaching. I have been studying English for many years. I want to correct mistakes that I might make. I search for new teaching techniques. I try to develop myself and reflect on my lessons.

Magda's future selves, in other words, the attributes that she would like to possess in the future include being a better teacher, someone who is conscious of students' desires and needs, more experienced and motivated to teach:

Each day, I want to become a more capable teacher, more conscious of what works and does not work for my students, someone who can listen to them and know what they think and want, what is good or not for them. Teachers need to learn always and seek for ways to improve their lessons.

Her ought-to self, that is, the representation of the attributes that she believes she should or ought to possess (e.g. her 24 Horizontes de Linguística Aplicada, ano 11, n. 2, jul./dez. 2012 
responsibilities and obligations with regard to her work), also revolves around the image of a teacher who is constantly improving and learning from her practice. According to Kubanyiova (2009, p. 316), the Ought-to Language Teacher Self "may involve latent expectations of colleagues, parents and students as well as the normative pressures of the school rules and norms".

Magda's ideal and ought-to positive selves may serve as impulse and, therefore, generate motivation as she will put effort in trying to achieve them. Although the dissonance between her desired selves and her actual selves is not huge, she states that sometimes "she doesn't get things right". She feels the necessity of improvement as an English teacher.

Leonard also creates a set of positive actual representations. He believes he is patient and worried about students' motivation and learning. He views himself as someone who contributes to form students' opinions, hardworking and flexible to deal with contextual constraints. He is also self-conscious of the impact of his decisions and practices on students' behavior:

I think I am worried about my students and I have patience in a sense, because I keep talking and calling students' attention, asking them to complete the exercises. I check if they could understand my instructions and explanations.

I am always reflecting on my profession and I talk to more experienced teachers that work with me.

As I pointed out, these positive actual self-images may work as motivators, since they reinforce Leonard's high self-efficacy:

I know the contents I have to teach. What I feel anxious about is the methodologies that I am testing with students. This can be a negative influence to teaching.

In this excerpt, when Leonard mentions the methodologies that he is putting into practice, he means tasks and techniques that are not included in the textbook adopted by the school. Not having a "script" to introduce these tasks and guidelines on how to make them appropriate for his students causes him a certain level of anxiety; in

Horizontes de Linguística Aplicada, ano 11, n. 2, jul./dez. 2012 
other words, he worries about students' engagement in these tasks, how they will react to them and if they will be motivated. The selfbelief Leonard has that revolves around the teacher's necessity of "dominating" methodologies impacts on his behavior. Though English is a compulsory course, there are local policies in primary education that focus on social promotion by learning cycles and deny school retention. Students are not evaluated by exams and cannot fail English, unless they do not attend classes. In this case, grades cannot function as extrinsic motivators. In order to get students' attention and participation in class, teachers have to think about ways to elaborate interesting activities and monitor students. This explains Leonard's concerns about the impact and efficacy of his methodologies on students. He also thinks about how to implement strategies and tasks that will facilitate students' learning. These concerns are not at all negative - they are part of the day-to-day tasks of a teacher and they may serve as a stimulus for change. For example, motivating students and contributing to their learning can lead teachers to mobilize resources to accomplish certain tasks.

Although Leonard is confident about his competence to teach English for elementary students, there is still a "gap" that he wants to fulfill in order to be a better teacher. This "gap" concerns the approach he uses with his students, but not the knowledge of the language and the contents he needs to teach them. Being able to use new methodologies in a confident way is part of Leonard's desired self what he could become in the future. He also wishes to be respected by his students, be more patient, be more mature to deal with classroom events and be resistant to the contextual negative influences:

I'd like to be a teacher that would suffer less with the negative factors. By doing that, I'd be more motivated I'd like that students would naturally understand that they have to stop and pay attention to the teacher because he wants to say something.

Leonard's ought-to self is constituted by images of a successful teacher in terms of tasks and materials designed to his students and the relationship with learners: 
I hope to have more success in the chosen methodologies and tasks. I want them to be more effective to students' learning.

I'd like to have more time and disposition to prepare materials to avoid using the textbook and the board.

I like to be close to students so that our relationship can be friendly and pleasant, but I'm more convinced each day that this is not advisable in this context.

In the previous examples, it is clear how Leonard feels compelled to act in a non-traditional way (e.g. prepare effective and more original tasks, be friendly with his students), because he thinks this should be his role or responsibility as a teacher, even though in some occasions his experience tells him that being that way is not positive at all. His ought-to self is constituted by actions to avoid negative results; in other words, to avoid being an unsuccessful teacher. Therefore, he keeps studying, reflecting and exchanging ideas with other teachers.

His ideal and ought-to self-images may stimulate his motivation to teach. As pointed out previously, possible selves may trigger or hinder teacher motivation, especially when there is a "gap" to be reduced between the actual and the desired end-states.

However, Leonard does not only form positive images about himself. By having the opportunity to watch and reflect on his lessons on the VSR sessions, he recognizes that he can also be boring, irritated, impatient, and unpleasant. Thus, many of his actual self-images are negative:

I could have expressed myself differently in this lesson not to sound boring. I was very boring... I'm very unfriendly.

When students ask me to repeat my instructions I get irritated and I say "I have just explained that", frowning.

Though I think that overall I'm patient in some situations I'm not.

In the interview, he also reveals an authoritative self:

Unfortunately, now I'm asking students to shut up and listen to me, because this way I can teach my lesson.

Horizontes de Linguística Aplicada, ano 11, n. 2, jul./dez. 2012 
These negative actual images demonstrate how Leonard struggles to keep himself motivated. Problems of indiscipline that teachers face in public schools play a role in the formation of Leonard's negative actual representations of himself. He recognizes his efforts to overcome the contextual difficulties ("At least I keep trying. I haven't given up yet") and reach his desired possible selves. Indeed, he fears being a boring, impatient, serious, impolite, insensitive teacher in the future, someone who does not care whether students are learning and enjoying his classes:

One of the worst problems is students' misbehavior. It makes me act more seriously and be impolite and this bothers me a lot because I don't like to be like that.

I should suffer less with all the adverse conditions and do what I was supposed to do and not be impatient, because the students who needed more explanations did not get them. I fear being a teacher that does not care about anything, I mean, someone that goes to class and doesn't say 'Good morning', someone who wants students to be quiet so that I can play my role and leave.

Negative self-images (actual or future) seem to be a powerful stimulating or imprisoning tool for Leonard. On the one hand, when he feels that his actual self is similar to his feared self and that the gap between his current self and his desired (positive) self is higher, he may strive to find ways to keep patient, improve his lessons and not give up.

My objective is not to feel so affected by the contextual problems, so I am trying to keep calm.

I always read varied books, even self-help books. I watch talk shows that stress the relationship between teenagers and adults in order to learn how to interact with them.

Self-help books always bring the discourse of the idealized or perfect self. These books constantly emphasize that by putting effort people can achieve success. In the education field, the various publications dedicated to English Language Teaching also bring hints 
and strategies that teachers can implement in order to successfully plan and run classroom activities, manage interactions and help students to speak and write. Here we can notice how various discourses and beliefs from a broader sociocultural context may influence teachers' desired self-beliefs, especially when we consider the high standards that society imposes on teachers. The effort expended by Leonard to fill the gap between his current and desired self and correspond to what society expects from him as a teacher may lead to satisfaction.

On the other hand, the negative images (the boring, irritated, impatient, and unpleasant self) can stifle his motivation, as he realizes no matter how hard he tries he may not be able to survive the negative influences and achieve his ideal self-images. As Kubanyiova points out (2009, p. 324), research on teacher motivation has concluded that "pressures of the system coupled with heavy workload, limited resources, prescribed curriculum, lack of autonomy or unsupportive colleagues have a negative impact on teacher commitment and development":

I don't want to be a teacher anymore. I realized that every year the routine is just the same. I teach eighth to ninth grade students. I teach them to care a little bit and be respectful, but then they leave and I meet new students and I have to do the same work all over again.

Repetition ("to do the same work all over again") is something negative to Leonard's motivation and is one of the reasons why he wants to leave the teaching profession. Routine is, in fact, part of any profession. However, within our society, there are many public discourses that idealize the teaching profession, emphasizing the idea of perfection and classifying teachers as good or bad. The teachers who conform to expected attitudes and behaviors from society (to this ought-to self), such as be motivated, hard-working and dedicated to students are seen as the good ones. Teachers who do not behave this way are seen as inadequate. These views can be harmful to education and are, in a way, responsible for teachers' lack of enthusiasm, demotivation, burnout and the loss of professionals.

Leonard is affected by this "pressure to be ideal" and, in the questionnaire, he confirms his desire to leave the teaching profession.

Horizontes de Linguística Aplicada, ano 11, n. 2, jul./dez. 2012 
When asked how he saw himself in five years, his answer was outright: "Out of the teaching profession". It is also part of his ideal selves not to be a teacher. His aspirations include having a career in the federal public service in another professional field. Thus, there is some discrepancy between this ideal self - being a federal worker - and his actual self - being a teacher. Leonard's identity is constituted of contradictions: he does not seem completely happy in the teaching profession, he keeps studying in order to find another job in the federal public sector, but he still invests in his practice by working hard to improve his lessons, being flexible and talking to more experienced teachers. His identity is formed by competing ideal selves. Also, he persists in his daily tasks, so that his actual selves will not match his feared images.

Just like Leonard, Magda also fears being an unhappy, impatient, demotivated, pessimistic and accommodated teacher, someone who does not care about students' learning:

I fear becoming an accommodated teacher, unhappy with my profession, someone who does not seek for new things and who teaches the same class for ten years and doesn't want to change.

However, unlike Leonard, she seems to suffer less (or deals better with) the negative influences that come especially from the teaching context. In the questionnaire, she indicates having dedication, effort and persistence in teaching. In the interview, she affirms that she is highly motivated to teach, and she wants to continue working and developing as a teacher:

I want to work. I have a great desire to keep working as a teacher. I have future plans, and I'm not unhappy because I know I will achieve them one day. I never give up. I have never stopped in the middle of a class, because I couldn't stand anymore.

For Magda, the feared images (e.g. accommodated, pessimistic, unsatisfied selves) do not seem to decrease her motivation. 
On the contrary, they seem to encourage her to find alternatives to meet her aspirations and keep herself motivated:

I try to read whatever is possible. I always try to study and attend events. I have just finished a specialization course and next year I want to enter the master's course.

I talk to my students or I give a break and I try to change my strategies sometimes. If I ask students to read a text and I realize nobody is doing that, nobody is responding, I finish the task or change my strategy and start a new activity that motivates students more. I try a few changes in order to motivate students and motivate myself.

Although Magda feels highly motivated to teach, that is, although her intrinsic motivation is high, she notices that her enthusiasm changes due to students' participation (an external factor). The same happens to Leonard. Students' lack of interest and participation in class, as well as their misbehavior are the most mentioned sources of demotivation for Magda and Leonard. As Dörnyei and Ushioda (2011, p. 163) highlight, "even with the best possible match between a profession and an individual, one's intrinsic motivation will be inevitably 'tainted' by the impact of external conditions and constraints". In other words, although a teacher may choose a profession that satisfies his/her personal interests and professional desires, it is important to consider that aspects from the environment also play a crucial role, leading to job satisfaction or dissatisfaction. The environmental issues that are mentioned by Leonard and Magda cover aspects from the microcontext of teaching, such as students' interest and participation in class, resources and sufficient conditions to deliver classes, support from other teachers, class sizes and salaries, as well as aspects from the macrocontext of teaching, such as expectations from the society about the roles that should be played by teachers (being a perfect teacher) and that impact on their ought-to selves.

It is significant in our data the dissonance between the teachers' ideal or ought to selves and their actual selves and this has consequences for their motivation. Magda's and Leonard's ideal selves basically revolve around being better teachers: motivated, more

Horizontes de Linguística Aplicada, ano 11, n. 2, jul./dez. 2012 
experienced, respected, patient, and confident in delivering lessons and dealing with environmental influences. These ideal representations do not differ substantially from their ought-to selves, which are formed by "external pressures, demands and requirements" (KUBANYIOVA, 2009, p. 321), that is, roles that are expected of them (by parents, students, and society as a whole). Therefore, their ought-selves include being successful, having a good relationship with students (which is seen as something that can increase motivation) and be constantly improving as a teacher. There is no significant discrepancy between their ideal and ought-selves. Contextual pressures and expectations have been ingrained in their ought-to selves. Both teachers try to live up to these expectations, and as they do that by putting effort on their tasks they reduce the dissonance between their ideal/ough-to selves and their actual selves.

In Figure 1, the increase and decrease of the teachers' motivation are represented as these teachers reduce (or not) the discrepancy between their actual and desired (ideal and ought-to) selves. This means that dissonance between current and possible selves (desired or feared) triggered by contextual factors may enhance or undermine motivation:

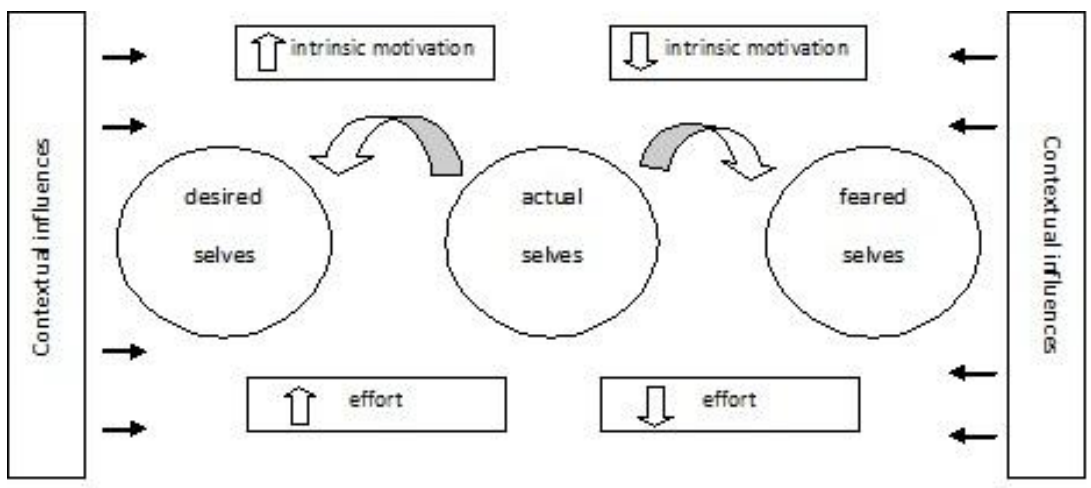

Figure 1: The influence of actual and possible selves on the teachers' motivation

\section{Conclusion}


The aim of this article was to highlight aspects of the motivation of two English elementary school teachers, in light of selftheories. I presented and discussed the actual and the possible images that these teachers create about themselves, and I emphasized their impact on motivation.

Actual and future self-beliefs were classified here as internal influences to teacher motivation. I demonstrated that they represent a twofold impact: they can help increase or decrease the teachers' motivation. Positive actual images may reinforce an optimistic view of one's competence and achievement. Future positive images can also serve as impulse for teachers and, therefore, generate motivation as they will persist in trying to achieve their ideal and ought-to self images. Negative actual self-images can be stimulating or imprisoning. On the one hand, they can pave the way to changes, that is, they can make teachers strive to find ways to keep trying and not give up. On the other hand, these images can stifle their motivation, as they may realize no matter how hard they try they will not succeed and achieve their ideal or ought to selves. The path to their desires and aspirations may be too long. The same happens to the role played by feared images, that is, what teachers are afraid of becoming. Those representations may encourage teachers to persist in their daily tasks. However, as I have showed, Magda and Leonard may be influenced by these images differently. These findings support the tenets of Higgin's discrepancy theory (1987) and Markus and Nurius' possible selves theory (1986), which stress the role of self-guides in behavior and motivation. Self-theories help us understand how teachers' thinking affects their motivation and engagement in teaching (USHIODA; DÖRNYEI, 2012).

Motivation will only arise if there is an observable gap between current and future selves (DÖRNYEI; USHIODA, 2011). Results show that the teachers' ideal selves may not be too different from their ought-to selves. This happens because what teachers see as ideal to them may be shaped by what they feel they should possess, according to the duties, obligations and responsibilities imposed by beliefs and discourses from a broader sociocultural context. However, we could notice a discrepancy between the teachers' actual and desired 
(ideal and ought to) selves and their effort to reduce this gap and not be like their feared selves, that is, "someone that they could become if either the ideals or perceived obligations and responsibilities are not lived up" (KUBANYIOVA, 2009, p. 316).

In addition, we cannot forget to mention the interaction of teachers' selves with contextual factors. Although Dörnyei's new model of motivation stresses the power of future self-guides in motivation, the author does not exclude motives related to the immediate learning environment and experience. Thus, as we have discussed, negative contextual influences (e.g. students' misbehavior) may contribute to shape Leonard's negative actual beliefs about himself as a boring, irritated, impatient, and unpleasant teacher. These problems cause him a desire not to work as a teacher anymore. Though more optimistic, Magda also feels the impact of the school context in her motivation.

Individuals' awareness of any dissonance in their selves is important for promoting change. Therefore, the investigation of teachers' self-beliefs is necessary in teacher education and continuing education programs. Open-ended interviews, reflective journals, autobiographies and oral histories can be used to trace teachers' selfbeliefs. Based on these findings, researchers and educators can elaborate intervention programs to make teachers gain a sense of their own vision of possible selves and the contradictions that constitute their self. Teachers can reflect on how to develop strategies to attain their desired selves (or change them), by connecting their current action to future goals.

It is important to provide teachers (and future teachers) with opportunities to reflect, discuss, and share teaching experiences, that is, what they are learning throughout their education and practice. VSR sessions have proved to be a useful tool in collaborating with teacher's reflective process, since they allow them to think back about their selfbeliefs, decisions, feelings, actions, and their impact on students' motivation and learning. As Kubanyiova (2009, p. 328) states: "without individuals' awareness of a discrepancy between their actual and possible selves, which is accompanied by dissonance emotions, there is no gap to be reduced". In this sense, VSR sessions could be an effective technique to make teachers aware of the factors that have an 
impact on their motivation, and reduce their anxiety if implemented in collaborative sessions involving teacher educators and teachers. Teachers need to realize that some of the factors that have a negative impact on their enthusiasm can be changed.

By reflecting on their practice, feelings and self-beliefs (and not only acting by intuition), teachers can expand their knowledge, broaden their repertoire of teaching strategies and improve the opportunities of learning offered to students. Teachers should look inside themselves and their courses in order to motivate themselves and their students. One of the tasks of teaching should be to engender a positive rather than negative motivational cycle in schools.

\section{References}

BORG, Simon. Teacher cognition in language teaching: a review of research on what language teachers think, know, believe, and do. Language Teaching, v. 36, 2003, p. 81-109.

BROWN, H.Douglas. Principles of language learning and teaching. Englewood Cliffs, Prentice Hall, 1994.

BISHAY, Andre. Teacher motivation and job satisfaction: a study employing the experience sampling method. Journal of Undergraduate Sciences, v. 3, p. 147-154, 1996

COATES; Thomas J.; THORESEN, Carl E. Teacher anxiety: a review with recommendations. Review of Educational Research, v. 46, n. 2, p. 159-184, 1976.

DAY, Christopher.; KINGTON, Alison.; STOBART, Gordon.; SAMMONS, Pam. The personal and professional selves of teachers: stable and unstable identities. British Educational Research Journal, v. 32, n. 4, p. 601-616, 2006.

DECI, Edward L.; KASSER, Tim.; RYAN, Richard M. Selfdetermined teaching: opportunities and obstacles. In: BLESS, James L. (Ed). Teaching well and liking it: motivating faculty to teach 
effectively. Baltimore, USA: The Johns Hopkins University Press, 1997, p. 57-71.

DÖRNYEI, Zoltan. Teaching and researching motivation. England: Longman, 2001a.

. New themes and approaches in second language motivation research, Annual Review of Applied Linguistics, v. 21, p. 43-61, 2001b.

. The psychology of the language learner: Individual Differences in Second Language Acquisition. New Jersey: Lawrence Erlbaum Associates Publishers, 2005.

DÖRNYEI, Zoltan; USHIODA, Ema. (orgs). Teaching and researching motivation. Harlow: Longman, 2011.

GILLHAM, Bill. Case study research methods. Londres e Nova Iorque: Continuum, 2000.

HARGREAVES, A. The emotional practice of teaching, Teaching and Teacher Education, v. 14, n. 8, p. 835-854, 1998.

HIGGINS, Edward Tory. Self-discrepancy theory. Psychological Review, v. 94, n. 3, p. 319-340, 1987.

KUBANYIOVA, Maggie. Possible selves in language teacher development. In: DÖRNYEI, Zoltan; USHIODA, Ema. (orgs). Motivation, language identity and the L2 self. Bristol, Buffalo, Toronto: Multilingual Matters, 2009, p. 314-332.

LAMB, Martin. Integrative motivation in a globalizing world. System, v. 32, p. 3-19, 2004.

LEONDARI, Angeliki.; SYNGOLLITOU, Efi.; KIOSSEOGLOU, Grigoris. Academic achievement, motivation and possible selves. Journal of Adolescence, v. 21, p. 219-222, 1998.

MARCUSCHI, Luiz Antônio. Análise da conversação. São Paulo: Ed. Ática, 2000. 
MARKUS, Hazel.; NURIUS, Paula. Possible selves. American Psychologist, v. 41, n. 4, p. 954-969, 1986.

MARKUS, Hazel.; WURF, Elissa. The dynamic self-concept. Annual Review of Psychology, v. 38, p. 299-337, 1987.

MORGAN, Mike.; KITCHING, Karl.; O'LEARY, Michael. The Psychic Rewards of Teaching: examining global, national and local influences on teacher motivation. In: ANNUAL MEETING OF THE AMERICAN EDUCATIONAL RESEARCH ASSOCIATION, 2007, Chicago, EUA.

OYSERMAN, Daphna. Self-concept and identity. In: TESSOR, Abraham; SCHWARZ, Norbert (Ed). Blackwell Handbook of Social Psychology. New York: Oxford University Press, 2001, p. 499 - 517.

OYSERMAN, Daphna.; JAMES, L. Possible selves: from content to process. In: MARKMAN, K.; KLEIN, William M.P.; SUHR, Julie A. (eds). The handbook of imagination and mental stimulation. New York: Psychology Press, 2009, p. 373-394.

PENNINGTON, Martha C. Work satisfaction and the ESL profession. Language, Culture and Curriculum, v. 4, n. 1, p. 59-86, 1991.

POWELL, E. Conceptualizing and facilitating active learning: teacher's video-stimulated reflective dialogues. In: BRITISH EDUCATIONAL RESEARCH ASSOCIATION CONFERENCE, 2004, Manchester, England.

PRAVER, Max.; OGA-BALDWIN, William. What motivates language teachers: investigating work satisfaction and second language pedagogy. Polyglossia, v. 14, p. 1-8, 2008.

REITANO, Paul. The value of video stimulated recall in reflective teaching practices. In: AUSTRALIAN CONSORTIUM FOR SOCIAL AND POLITICAL RESEARCH INC. (ACSPRI) SOCIAL SCIENCE METHODOLOGY CONFERENCE, 2006, New South Wales. 
RUVOLO, Ann.; MARKUS, Hazel. Possible selves and performance: the power of self-relevant imagery. Social Cognition, v. 10, p. 95-124, 1992.

SINCLAIR, Kenneth E.; BARNES, Jenny. Can anxiety about teaching be measured? In: AARE'S CANBERRA CONFERENCE PAPERS, 2009, Canberra, Australia.

USHIODA, Emma; DÖRNYEI, Zoltan. Motivation. In: GASS, Susan.; MACKEY, Alison. (Ed). The Routledge handbook of second language acquisition. New York: Routledge, 2012, p. 396-409.

WALKER, Charles J.; SYMONS, Cynthia. The meaning of human motivation. In: BLESS, James L. (ed). Teaching well and liking it: motivating faculty to teach effectively. Baltimore, USA: The Johns Hopkins University Press, 1997, p. 3-18.

YASHIMA, Tomoko. Autonomy and willingness to communicate. Development of an English-using ideal self. In: INDEPENDENT LEARNING ASSOCIATION JAPAN CONFERENCE, 2007, Chiba, Japan.

ZEMBYLAS, Michalinos. Beyond teacher cognition and teacher beliefs: the value of the ethnography of emotions in teaching. International Journal of Qualitative Studies in Education, v.18, n. 4, p. 465-487, 2005.

Submitted on: Nov 10, 2012

Accepted on: Jan 31, 2013

Título: A motivação de professores de inglês de escola pública: o que as teorias do "eu” podem nos dizer? 